plantejaments onto-polítics d'Arendt que no dubta en criticar-la quan considera que la pròpia autora no està a l'alçada del que promet. És aquest el motiu de la crítica a Arendt quan aquesta es mostra, als seus ulls, com incapaç de pensar la imaginació política amb tota la càrrega creativa que implica aquesta capacitat. Segons Zerilli, Arendt resta engarjolada en l'exposició d'una imaginació purament reproductiva que no pot donar compte de com funciona aquell procés de reflexió i intercanvi de judicis que dóna lloc a aquest "nosaltres". El "nosaltres" no és susceptible de ser establert per categories externes al moment mateix del polític i, mitjançant l'exercici del judici, està en disposició de posar en crisi contínuament les regles que van establint-se progressivament, atès que aquestes poden acabar per negar la llibertat.

En definitiva, es pot estar d'acord o en desacord amb aquesta i amb moltes altres de les nombroses perspectives d'anàlisi que l'autora d'aquest volum va desgranant, però el que resulta innegable per a qui la llegeix és que la seua és una aportació del tot valuosa tant per a la teoria feminista, com per a la teoria política de la democràcia radical i per als estudis del pensament arendtià. I, dit de passada, paga la pena no precipitar-se amb arguments que es reclamen "més realistes" contra aquesta veu que ens alerta que el feminisme és "una improbabilitat infinita" i que la llibertat es basta a si mateixa per donar-li sentit.

ÀNGELA LORENA FUSTER Universitat de Barcelona

\title{
Frames of War: When Is Life Grievable?
}

\section{Judith Butler}

London-New York, Verso, 2009

La tesis principal de Butler en Frames of War es que los marcos interpretativos por medio de los cuales nos es posible entender la violencia son parte material y esencial del propio acto de librar una guerra. Del mismo modo que un contenido y su envoltorio a veces no pueden separarse, lo que entendemos como "contenido" (el hecho bélico) está necesariamente enmarcado y no es posible aproximarse a él ajeno a los marcos que lo vehiculan. El marco es una estrategia activa de contención que no sólo contiene lo que es sino también su justificación y su interpretación, y en un contexto de guerra el marco dictamina, además de la justificación, la distinción entre las vidas que merecen ser preservadas y lloradas, y las que no.

Así, partiendo de la premisa de que las normas de reconocibilidad no son un potencial inherente a los individuos, sino que son producidas para hacer que algunos sujetos sean más reconocibles que otros, Butler denuncia las políticas 
diferenciales en cuanto a la formación de sujetos propuestas por los distintos mapas de poder contemporáneos, sobre todo en el contexto de guerra actual. Se preguntará a lo largo de la obra si y qué nuevas condiciones, más equitativas y democráticas, son posibles y para acercarnos a ellas sostendrá que es necesario que la teoría moral se convierta en crítica social para, conociendo su objeto, poder actuar sobre él. Para ello, Butler sostiene que es necesario repensar, en primer lugar, la ontología del ser, inevitablemente ligado a las estructuras sociales y políticas. Debido a que, para Butler, es imposible pensar en las propiedades fundamentales del ser como algo separado de los otros, las normas y las organizaciones desarrolladas para interpelarlo, en suma, porque estamos constituidos y a la vez desposeídos por los otros - "we are undone by each other"-, es necesario volver a plantearse qué es "la precariedad, la vulnerabilidad, la dañabilidad, la interdependencia, la desprotección, la persistencia corporal, el deseo, el trabajo y las reivindicaciones respecto al lenguaje y a la pertenencia social".

En segundo lugar, Butler reflexiona acerca del impacto político y social que pueden tener ciertos documentos al hacerse públicos fuera de los marcos en los que fueron producidos. Para ello, dialoga con Sontag, que en Regarding the Pain of Others (2003) y en On Photography (1977) sostenía que la fotografía tenía la capacidad de conmovernos momentáneamente pero que, al carecer de un marco narrativo, no nos permitía comprender lo representado y desarrollar una interpretación. La pregunta clave que se hacía Sontag era si las fotos aún tenían - o tuvieron alguna vez - el poder de transmitir el sufrimiento de otros de un modo tal que los observadores cambiaran su percepción política sobre la guerra. Debido a que, para Sontag, la representación del sufrimiento se había convertido en un cliché, sostenía que la fotografía no era capaz de producir un cuestionamiento de la realidad.

Sin embargo, en 2003 Sontag sostiene que, aunque la fotografía es incapaz de dirigir una acción política - a pesar de poder provocar indignación-, sí tiene la capacidad de atormentarnos y de mostrarnos la vulnerabilidad de la vida, que está siempre acercándose a la muerte (en comunión con la noción desarrollada por Barthes en Camera Lucida, donde la fotografía es capaz de reflejar una vida en el futuro anterior). Para Butler, debido a que la imagen sobrevive a la vida que documenta, su capacidad para establecer por adelantado el tiempo en que esa vida se perderá es lo que conecta a esa vida con la posibilidad de ser llorada. Si bien las fotos no pueden evitar o apaciguar el dolor de la persona encerrada y torturada, las imágenes apelan a esa posibilidad. De este modo, para Butler la cultura visual tiene un papel crucial en tiempos de guerra porque es capaz de denunciar y superar los marcos, esos marcos forzosos que no son fáciles de ver y que normalmente nos ciegan, y que sólo conducen hacia la norma deshumanizadora.

Así, es gracias a la distribución diferencial de la vulnerabilidad que se puede llevar a cabo una guerra. A partir de una definición geopolítica del tiempo como 'moderno' o 'pre-moderno', y bajo el supuesto de extender las libertades modernas y democráticas a las comunidades consideradas pre-modernas, se 
legitiman ciertas políticas sociales, determinados imaginarios nacionales y algunas políticas progresistas que a veces tienen efectos claramente xenófobos y misóginos. Por ello, para Butler el marco tiene un doble significado: el de marco o perspectiva (frame) y el de ser incriminado (to be framed), de manera que el marco puede funcionar tanto para guiar la interpretación como para acusar falsamente, por lo que si un hecho es 'enmarcado', el marco sirve para conducir hacia una conclusión inevitable. Sin embargo, ante la ruptura de un marco ya no hay regulación y control de la interpretación y de la respuesta afectiva y se abre un espacio de libertad para reaccionar de un modo más autónomo y crítico, para la concienciación, la denuncia, la resistencia y la acción política.

Tal es el caso de la filtración de las fotografías de tortura, asesinato y vejación de prisioneros en la cárcel de Abu Ghraib, tomadas dentro de un marco que exalta la tortura y la vejación de prisioneros islámicos como elementos necesarios para la defensa del estado norteamericano, pero que, una vez se escapan del marco, producen el efecto contrario y se revelan como una escenificación sádica.

Por lo tanto, Butler niega que los marcos interpretativos sean impermeables $\mathrm{y}$ es precisamente por ello que las condiciones sociales pueden (y deben) ser dinámicas. De no ser así, el ser humano no tendría ningún tipo de responsabilidad para con sus semejantes, incluso a pesar de su absoluta dependencia de las relaciones sociales para la preservación de la vida. Frames of War: When Is Life Grievable? apela a la responsabilidad del individuo hacia una acción política que garantice un reparto más democrático de la precariedad (el reconocimiento de que podemos morir) y la vulnerabilidad (el reconocimiento de que debemos ser cuidados) y que, como consecuencia, extienda más equitativamente la dignidad de poder ser llorados.

DOLORES RESANO

Universitat de Barcelona 